\title{
Sirohaem sulfite reductase and other proteins encoded by genes at the dsr locus of Chromatium vinosum are involved in the oxidation of intracellular sulfur
}

\author{
Andrea S. Pott and Christiane Dahl \\ Author for correspondence: Christiane Dahl. Tel: +49228732119 . Fax: +49228737576. \\ e-mail:ChDahl@uni-bonn.de
}

Institut für Mikrobiologie \& Biotechnologie, Rheinische FriedrichWilhelms-Universität Bonn Meckenheimer Allee 168 D-53115 Bonn, Germany

\begin{abstract}
The sequence of the dsr gene region of the phototrophic sulfur bacterium

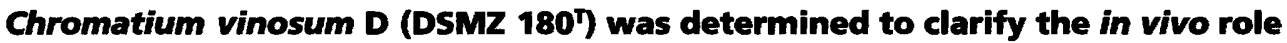
of 'reverse' sirohaem sulfite reductase. The dsrAB genes encoding dissimilatory sulfite reductase are part of a gene cluster, dsrABEFHCMK, that encodes four small, soluble proteins (DsrE, DsrF, DsrH and DsrC), a transmembrane protein (DsrM) with similarity to haem-b-binding polypeptides and a soluble protein (DsrK) resembling [4Fe-4S]-cluster-containing heterodisulfide reductase from methanogenic archaea. Northern hybridizations showed that expression of the dsr genes is increased by the presence of reduced sulfur compounds. The dsr genes are not only transcribed from a putative promoter upstream of dsrA but primary transcripts originating from (a) transcription start site(s) downstream of dsrB are also formed. Polar insertion mutations immediately upstream of dsrA, and in dsrB, dsrH and dsrM, led to an inability of the cells to oxidize intracellularly stored sulfur. The capability of the mutants to oxidize sulfide, thiosulfate and sulfite under photolithoautotrophic conditions was unaltered. Photoorganoheterotrophic growth was also unaffected. 'Reverse' sulfite reductase and DsrEFHCMK are, therefore, not essential for oxidation of sulfide or thiosulfate, but are obligatory for sulfur oxidation. These results, together with the finding that the sulfur globules of $C$. vinosum are located in the extracytoplasmic space whilst the dsr gene products appear to be either cytoplasmic or membranebound led to the proposal of new models for the pathway of sulfur oxidation in this phototrophic sulfur bacterium.
\end{abstract}

Keywords: Chromatium vinosum, sulfur oxidation, reverse sirohaem sulfite reductase, extracytoplasmic sulfur globules, heterodisulfide reductase

\section{INTRODUCTION}

A wide variety of enzymes catalysing sulfur redox reactions have been isolated from phototrophic sulfur bacteria (Trüper \& Fischer, 1982; Fischer, 1989; Brune, 1989; Dahl \& Trüper, 1994; Brune, 1995a). However, to some of these, specific in vivo functions could not be assigned. Flavocytochrome $c$ (Dolata et al., 1993; Chen et al., 1994) and sirohaem sulfite reductase (Schedel et al., 1979) are only two examples of biochemically wellcharacterized proteins whose roles in the oxidation of

The GenBank accession number for the sequence reported in this paper is U84760. reduced sulfur compounds are still unclear. On the other hand, the enzymes responsible for several of the sulfur transformations catalysed by phototrophic sulfur bacteria, among them the oxidation of sulfide and sulfur, have not conclusively been identified.

Two possibilities have been discussed for the initial step in sulfide oxidation, the first of which is oxidation to elemental sulfur catalysed by a sulfide dehydrogenase. The sulfide dehydrogenase has been proposed to be flavocytochrome $c$, other $c$-type cytochromes or sulfide:quinone oxidoreductase, depending on the organism studied (reviewed by Brune, 1989, 1995a). It has also been proposed that $\mathrm{H}_{2} \mathrm{~S}$ might, at least in part, be oxidized directly to sulfite by a sirohaem sulfite reductase 
Table 1. Bacterial strains and plasmids

\begin{tabular}{|c|c|c|}
\hline $\begin{array}{l}\text { Bacterial strain or } \\
\text { plasmid }\end{array}$ & Genotype or phenotype & Source or reference \\
\hline \multicolumn{3}{|l|}{$\begin{array}{l}\text { Escherichia coli } \\
\text { strains }\end{array}$} \\
\hline $\mathrm{DH} 5 \alpha$ & $\begin{array}{l}\mathrm{F}^{-} \phi 80 \mathrm{~d} l a c Z \Delta \mathrm{M} 15 \Delta(\operatorname{lacZYA-arg} F) U 169 \operatorname{recA} 1 \text { endA1 } b s d R 17\left(\mathrm{r}_{\mathbf{K}}^{-} \mathrm{m}_{\mathrm{K}}^{+}\right) \operatorname{supE44} \\
\lambda^{-} \text {thi-1 gyrA relA1 }\end{array}$ & Hanahan (1983) \\
\hline SM10 & $\begin{array}{l}\mathrm{Km}^{\mathrm{r}} \text {, supE44 thi-1 thr-1 recA leuB6 lacY1 tonA21 RP4-2-Tc::Mu-Km::Tn7 } \\
\text { in chromosome }\end{array}$ & Simon et al. (1983) \\
\hline \multicolumn{3}{|l|}{$\begin{array}{l}\text { Chromatium vinosum } \\
\text { strains }\end{array}$} \\
\hline SM50 & $\mathrm{Sm}^{\mathrm{r}}$, spontaneous streptomycin-resistant mutant of C. vinosum $\mathrm{DSM} 180^{\mathrm{T}}$ & Dahl (1996) \\
\hline $31 \mathrm{D}$ & $\mathrm{Sm}^{\mathrm{r}} \mathrm{Km}^{\mathrm{r}}, d s r B:: \mathrm{Km} \Omega\left(\mathrm{Km}^{\mathrm{r}}\right.$ in the same orientation as $\left.d s r B\right)$ & This work \\
\hline 21D & $\mathrm{Sm}^{\mathrm{r}} \mathrm{Km}^{\mathrm{r}}, d s r B:: \mathrm{Km} \Omega\left(\mathrm{Km}^{\mathrm{r}}\right.$ in the opposite orientation to $\left.d s r B\right)$ & This work \\
\hline 34D & $\mathrm{Sm}^{\mathrm{r}} \mathrm{Km}^{\mathrm{r}} d s r H:: \mathrm{Km} \Omega$ & This work \\
\hline $35 \mathrm{D}$ & $\mathrm{Sm}^{\mathrm{r}} \mathrm{Km}^{\mathrm{r}}, d s r M:: \mathrm{Km} \Omega$ & This work \\
\hline $34 \mathrm{~S}$ & $\mathrm{Sm}^{\mathrm{r}} \mathrm{Km}^{\mathrm{r}}, \mathrm{Ap}^{\mathrm{r}}, d s r M:: \mathrm{pAP} 34$ & This work \\
\hline 37D & $\mathrm{Sm}^{\mathrm{r}} \mathrm{Km}^{\mathrm{r}}, 236 \mathrm{bp}$ upstream of $d s r A:: \mathrm{Km} \Omega$ & This work \\
\hline \multicolumn{3}{|l|}{ Plasmids } \\
\hline pBluescript SK II (+) & $\mathrm{Ap}^{\mathrm{r}} \operatorname{lacZ}^{\prime}$ f1 ori & Stratagene \\
\hline pSUP202 & $\mathrm{Ap}^{\mathrm{r}} \mathrm{Cm}^{\mathrm{r}} \mathrm{Tc}^{\mathrm{r}}$, RP4 oriT ColE1 ori & Simon et al. (1983) \\
\hline pSUP301 & $\mathrm{Ap}^{\mathrm{r}} \mathrm{Km}^{\mathrm{r}}, \mathrm{RP} 4$ oriT $\mathrm{p} 15 \mathrm{~A}$ ori & Simon et al. (1983) \\
\hline pAP1a and pAP1b & $\begin{array}{l}\mathrm{Ap}^{\mathrm{r}}, 4.8 \mathrm{~kb} \text { XhoI fragment in XhoI of pBluescript SK II(+), orientations A } \\
\text { and B }\end{array}$ & This work \\
\hline pAP10 & $\mathrm{Ap}^{\mathrm{r}}, 3.9 \mathrm{~kb}$ Sall fragment in SalI of pBluescript SK II $(+)$ & Hipp et al. (1997) \\
\hline pAP50a and pAP50b & $\begin{array}{l}\mathrm{Ap}^{\mathrm{r}}, 4.06 \mathrm{~kb} \text { BgllI fragment in Bam HI of pBluescript SK II (+), orientations A } \\
\text { and B }\end{array}$ & This work \\
\hline pAP2 & $\mathrm{Ap}^{\mathrm{r}}, 3 \cdot 1 \mathrm{~kb}$ EcoRI fragment in EcoRI of pUC18 & Hipp et al. (1997) \\
\hline pAP20a & $\mathrm{Tc}^{\mathrm{r}} \mathrm{Ap}^{\mathrm{r}}, 3 \cdot 1 \mathrm{~kb}$ EcoRI fragment in EcoRI of pSUP202 & This work \\
\hline pAP21 & $\mathrm{Km}^{\mathrm{r}} \mathrm{T}^{\mathrm{r}} \mathrm{Ap}^{\mathrm{r}}, \mathrm{Km}^{\mathrm{r}}$ cartridge (EcoRI) from $\mathrm{pHP} 45 \Omega$ in $S m a \mathrm{I}$ of pAP20a & This work \\
\hline pAP30 & $\mathrm{Ap}^{\mathrm{r}}, 3.1 \mathrm{~kb}$ EcoRI fragment in SmaI of pSUP301 & This work \\
\hline pAP31 & $\mathrm{Km}^{\mathrm{r}} \mathrm{Ap}^{\mathrm{r}}, \mathrm{Km}^{\mathrm{r}}$ cartridge (EcoRI) from $\mathrm{pHP} 45 \Omega$ in $S m a \mathrm{I}$ of pAP30 & This work \\
\hline pAP33a and pAP33b & $\begin{array}{l}\mathrm{Ap}^{\mathrm{r}}, 2 \cdot 3 \mathrm{~kb} \text { Eco109I fragment from pAP1b in SmaI of pSUP301, orientations } \\
\mathrm{A} \text { and B }\end{array}$ & This work \\
\hline pAP34 & $\mathrm{Km}^{\mathrm{r}} \mathrm{Ap}^{\mathrm{r}}, \mathrm{Km}^{\mathrm{r}}$ cartridge (EcoRI) from $\mathrm{pHP} 45 \Omega$ in $E c o \mathrm{RI}$ of $\mathrm{pAP} 33 \mathrm{a}$ & This work \\
\hline pAP35 & 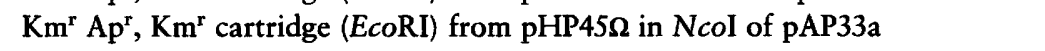 & This work \\
\hline pAP36a and pAP36b & $\begin{array}{l}\text { Ap } \mathrm{r}, 3.9 \mathrm{~kb} \text { SalI fragment from pAP10 in SmaI of pSUP301, orientations A } \\
\text { and B }\end{array}$ & This work \\
\hline pAP37 & $\mathrm{Km}^{\mathrm{r}} \mathrm{Ap}^{\mathrm{r}}, \mathrm{Km}^{\mathrm{r}}$ cartridge (EcoRI) from $\mathrm{pHP} 45 \Omega$ in $E c o \mathrm{RV}$ of $\mathrm{pAP} 36 \mathrm{a}$ & This work \\
\hline $\mathrm{pHP} 45 \Omega$ & $\mathrm{Km}^{\mathrm{r}} \mathrm{Ap}^{\mathrm{r}}$ & Fellay et al. (1987) \\
\hline
\end{tabular}

operating in reverse, an enzyme found in Chromatium vinosum $\mathrm{D}$ (Schedel et al., 1979). This protein is closely related to the dissimilatory sulfite reductases from sulfate-reducing bacteria and archaea (Hipp et al., 1997), enzymes which are generally located in the cytoplasm. During the oxidation of sulfide and thiosulfate, phototrophic sulfur bacteria of the family Chromatiaceae form sulfur as an intermediate which is stored inside the cell. In the light of the recent finding that the sulfur globules in C. vinosum are located extracytoplasmically (Pattaragulwanit et al., 1998) it appears impossible that cytoplasmic sulfite reductase can directly oxidize sulfur as has been proposed by Trüper (1984). It has also been hypothesized that the sulfur globules of phototrophic sulfur bacteria are formed on a side branch of the main sulfide oxidation pathway and must be reduced back to sulfide prior to further oxidation (Trüper, 1984). A cytoplasmic sulfite reductase could be essential for this pathway.

As experimental evidence has not been obtained for any of the suggested functions of sulfite reductase, we cloned and sequenced 5 '- and 3 '-flanking regions of the $C$. vinosum dsr $A B$ genes encoding this protein. Analysis of the sequence data and phenotypic characterization of strains with mutations at the $d s r$ locus allowed us to propose new models for the sulfur oxidation pathways in phototrophic sulfur bacteria.

\section{METHODS}

Bacterial strains and plasmids, media and growth conditions. The strains and plasmids used in this study are listed in Table 1. 
Escherichia coli strains were cultured in LB medium (Sambrook et al., 1989). IPTG and X-Gal were included in solid media to identify recombinant plasmids containing inserts in the $\alpha$ portion of lacZ. C. vinosum was grown and harvested as described earlier (Dahl \& Trüper, 1994; Pattaragulwanit \& Dahl, 1995; Dahl, 1996). Antibiotics were used at the following concentrations (in $\mu \mathrm{g} \mathrm{m}^{-1}$ ): for E. coli, ampicillin, 100; kanamycin, 50; tetracycline, 5; chloramphenicol, 100; for C. vinosum, kanamycin, 5; streptomycin, 50; ampicillin, 10 (solid media) or 100 (liquid media).

Recombinant DNA techniques. Standard methods were used for molecular techniques (Sambrook et al., 1989; Wilkinson, 1991; Ausubel et al., 1997). Chromosomal DNA of C. vinosum strains was obtained by Sarkosyl lysis (Bazaral \& Helinski, 1968) and purified by ethidium bromide/caesium chloride density-gradient centrifugation or by phenol/chloroform extraction and dialysis against water. Southern hybridizations were performed overnight at $68^{\circ} \mathrm{C}$ as described previously (Dahl et al., 1994). PCR with Taq DNA polymerase was done essentially as described by Dahl (1996). DNA probes for Southern and Northern hybridization experiments and screening of libraries were digoxigenin-labelled by PCR and colony hybridizations were performed following the protocol of Boehringer. Double-stranded DNA was sequenced with the Silver Sequence system (Promega) and universal and de-novosynthesized oligonucleotide primers. Nucleotide sequences were compiled and analysed with the DNAsIs software (Pharmacia).

Cloning of the $d s r$ locus. The region downstream of $d s r B$ was cloned by using a PCR-amplified fragment from nucleotide 1298 to 3037 of the sequence presented in Fig. 1 as a probe to identify several positive clones with a $4.8 \mathrm{~kb}$ XhoI insert in a library of $4.5-4.8 \mathrm{~kb}$ Xhol fragments of chromosomal $C$. vinosum DNA in the pBluescript vector. Sequencing of the positive clone pAP1a revealed the presence of several complete ORFs and one ORF that was truncated at the $3^{\prime}$ end. To analyse the missing part of this ORF, a clone with a $4 \mathrm{~kb}$ BglII fragment was isolated from a library of $3.5-4.5 \mathrm{~kb} B g l \mathrm{II}$ fragments in the pBluescript vector which had previously been digested with BamHI. A PCR-amplified fragment covering nucleotides $4086-4636$ of the complete sequence was used as a probe in this step.

Conjugative plasmid transfer and gene replacement. The plasmids used for the construction of C. vinosum strains with mutations in several of the $d s r$ genes are listed and described in Table 1. Mobilizable plasmids were transferred from $E$. coli SM10 to C. vinosum SM50 by conjugation (Pattaragulwanit \& Dahl, 1995). Transconjugants were selected on RCV (Weaver et al., 1975) plates with $0.3 \%$ malic acid and $0.5 \mathrm{~g}$ yeast extract $1^{-1}$ containing the appropriate antibiotics under anaerobic conditions in the light. Growth could be enhanced by addition of $20 \%$ PFAT (Pattaragulwanit \& Dahl, 1995) to the RCV plates. Approximately $95 \%$ of the recombinants analysed had lost the vector-encoded antibiotic resistance indicating that a double-crossover recombination had occurred. The genotypes of the C. vinosum recombinants used in this study were confirmed by Southern hybridization and PCR.

RNA isolation and Northern hybridizations. Total RNA from C. vinosum was isolated following the protocol for rapid RNA isolation from Gram-negative bacteria described by Ausubel et al. (1997). After precipitation of the RNA with ethanol a red pellet was obtained. The RNA was further purified using the RNeasy Total RNA kit (Qiagen). After addition of 0.8-1.0 U RNasin ribonuclease inhibitor (Promega) $\mu \mathrm{l}^{-1}$ the RNA was stored at $-70^{\circ} \mathrm{C}$. RNA was electrophoresed in agarose/formaldehyde gels $10.9 \%$ agarose, $6.3 \%$ formaldehyde, $1 \times$ MOPS buffer (40 mM MOPS, $10 \mathrm{mM}$ sodium acetate, $2 \mathrm{mM}$ EDTA, $\mathrm{pH} 7 \cdot 0$ ). Samples of $10 \mu \mathrm{g}$ RNA in a total volume of $8 \mu \mathrm{l}$ were mixed with $0.5 \mathrm{U}$ RNase-free DNase (Promega) and incubated for $5 \mathrm{~min}$ at $37^{\circ} \mathrm{C}$. Sixteen microlitres of freshly prepared sample buffer [75 $\mu \mathrm{l}$ deionized formamide, $30 \mu \mathrm{l} 37 \%$ formaldehyde, $30 \mu \mathrm{l}$ $5 \times$ MOPS, $15 \mu \mathrm{l} 10 \times$ dye $(50 \%$ glycerol, $1 \mathrm{mM}$ EDTA, $0.25 \%$ bromphenol blue) and $1 \mu 11 \%$ ethidium bromide] were added, followed by incubation at $65^{\circ} \mathrm{C}$ for $10 \mathrm{~min}$ and chilling on ice. The fragments of a $0 \cdot 24-9.5 \mathrm{~kb}$ RNA ladder (Life Technologies) were used as RNA size markers. The RNA was transferred and fixed to positively charged Nylon membranes (Boehringer) via capillary blotting and UV cross-linking. Hybridization with digoxigenin-labelled DNA fragments was performed essentially as described by Boehringer. The membranes were prehybridized in $0.75 \mathrm{M}$ sodium chloride, $0.075 \mathrm{M}$ sodium citrate, $\mathrm{pH} 7 \cdot 0,50 \%$ deionized formamide, $0 \cdot 1 \%$ sodium lauroylsarcosine, $0.02 \%$ SDS and $2 \%$ blocking reagent at $40^{\circ} \mathrm{C}$ for $4-6 \mathrm{~h}$. PCR-amplified DNA probes were purified by gel electrophoresis and isolation of the DNA with the QiaQuick Gel Extraction kit (Qiagen). After denaturation of the probe in prehybridization solution at $100^{\circ} \mathrm{C}$ for $10 \mathrm{~min}$, the prehybridization solution was discarded, the hybridization solution with the probe DNA was added and hybridization was continued for $12-16 \mathrm{~h}$ at $40^{\circ} \mathrm{C}$. Membranes were washed twice for $5 \mathrm{~min}$ in $2 \times \mathrm{SSC}, 0.1 \%$ SDS at room temperature and twice for $15 \mathrm{~min}$ in $0.1 \times \mathrm{SSC}, 0.1 \% \mathrm{SDS}$ at $40^{\circ} \mathrm{C}$. Chemiluminescent detection was performed following the instructions of Boehringer with the following modifications: anti-DIG Fab fragments were diluted 1:7500, CSPD was applied to a final concentration of $125 \mu \mathrm{M}$.

Turnover of reduced sulfur compounds. This was measured in batch culture and sulfur compounds were determined as described by Dahl (1996).

\section{RESULTS}

\section{Nucleotide sequence of the dsr locus}

Recently, we reported the cloning and sequencing of the genes, $d s r A$ and $d s r B$, encoding the two subunits of sirohaem sulfite reductase from C. vinosum (Hipp et al., 1997). As a further step in the systematic examination of this region, we cloned and sequenced upstream and downstream flanking regions and obtained a contiguous sequence of $6976 \mathrm{bp}$. Downstream of $d s r B$ six complete ORFs are present, which we termed dsrEFHCMK. These are closely spaced and all are preceded by putative ribosome-binding sites (Fig. 1). All six ORFs show a codon usage typical for C. vinosum (not shown) and a $\mathrm{G}+\mathrm{C}$ content ranging from 59.6 to $63.6 \mathrm{~mol} \%$, which is slightly lower than the $64.3 \%$ found for total C. vinosum DNA (Pfennig \& Trüper, 1989). A putative promoter region conforming to the consensus sequence of $E$. coli $\sigma^{70}$ promoters (Lisser \& Margalit, 1993) was found upstream of $d s r A$ (Fig. 1). Two inverted repeats with a potential for formation of hairpin loop structures (free energy of formation -92.8 and $-164.8 \mathrm{~kJ} \mathrm{~mol}^{-1}$ ) were found beween $d s r B$ and $d s r E$. These structures could function as transcription terminators; however, $\operatorname{poly}(\mathrm{T})$ sequences located directly downstream of such hairpin loops in typical eubacterial rho-independent transcription terminators (Reynolds et al., 1992) are not present in the C. vinosum sequence. 
1

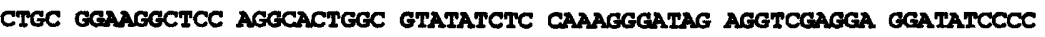
$-10$

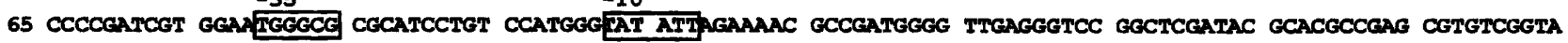

165 CCACCGGCTC CACACACAGA CCCGACGCGA TGCAGCGATC CGCGCTGTCC CGGCCAAGCG GTCGAGACAG GTTCGTGCAC GCGCACAAAC CATATCCGTT

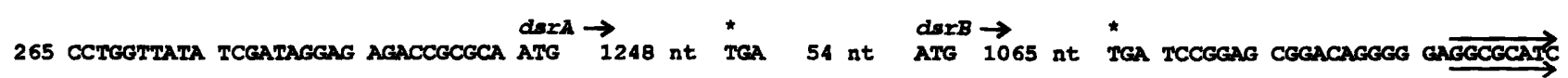

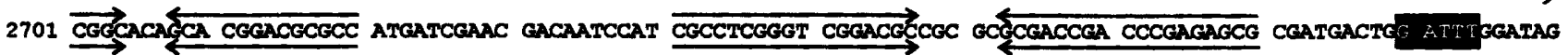

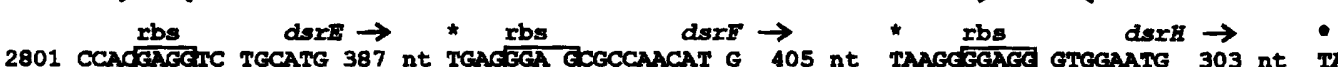

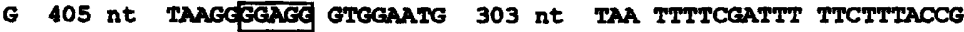

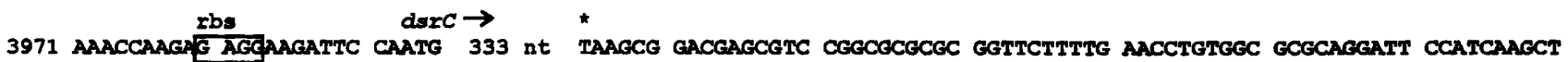

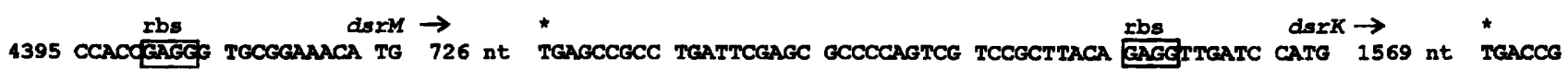

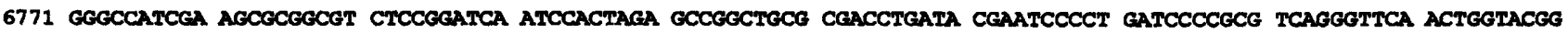

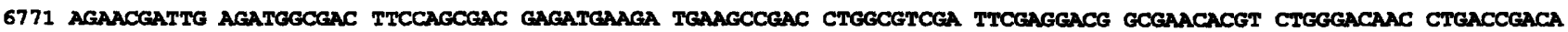
6871 AGATCT

Fig. 1. Partial nucleotide sequence of the $d s r$ locus of $C$. vinosum. The nucleotide sequence of the $d s r A$ and $d s r B$ genes (nt 295-2673) has been published elsewhere (Hipp et al., 1997). Putative ribosome-binding sites and promoter regions are boxed. Translation stop signals are marked by asterisks. Inverted repeats with the ability to form stable hairpin structures are indicated by arrows. The nucleotide sequence printed white on black conforms to the consensus sequence for RNase E cleavage sites published by Ehretsmann et al. (1992) and is located in the vicinity of two probable hairpin-loop-forming sequences.

\section{$d s r E, d s r F$ and $d s r H$ encode similar proteins}

$d s r E, d s r F$ and $d s r H$ encode polypeptides of 130,136 and 102 amino acids with calculated molecular masses of $14 \cdot 6,15 \cdot 6$ and $12 \cdot 6 \mathrm{kDa}$, respectively. The theoretical isoelectric points for these proteins lie at $\mathrm{pH} 5 \cdot 7,4 \cdot 2$ and $4 \cdot 7$, respectively. All three deduced proteins are predicted to be soluble and cytoplasmic due to the lack of regions able to form transmembrane helices and the lack of potential signal peptide sequences. A comparison of the derived protein sequences with sequences deposited in the databases was done with the $\Psi$-BLAST program (Altschul et al., 1997). The only matches found were with hypothetical proteins from E. coli, Haemophilus influenzae and methanogenic archaea (Table 2). Like $d s r E F H$, the matching $E$. coli and $H$. influenzae genes are juxtapositioned. In Methanobacterium thermoautotrophicum, the matching genes MTH1357, 1358 and 1360 are interrupted by only one gene MTH1359. Surprisingly, all three C. vinosum gene products showed low but significant similarity $(P$-values ranging from 0.036 to 0.14 ) to the hypothetical proteins MJ0989 (pir E64423) and ORF1 (gb Y10251) from Methanococcus jannaschii and Methanopyrus kandleri, respectively, indicating that DsrE, DsrF and DsrH are similar to each other. The alignment of their amino acid sequences (Fig. 2a) verified this assumption. The presence of related genes in E. coli, $H$. influenzae and methanogenic archaea, organisms which do not contain dissimilatory sulfite reductases but can synthesize assimilatory sirohaem sulfite and nitrite reductases under appropriate growth conditions, may hint at a function of the $d s r E F H$ encoded polypeptides in assembly, folding or stabilization of sirohaem proteins. This conclusion is, however, inconsistent with the observation that the genome of the sulfate reducer Archaeoglobus fulgidus, an organism that contains a dissimilatory sirohaem sulfite reductase (Dahl et al., 1993) does not contain similar genes (Klenk et al., 1997).

\section{The dsrC-encoded protein is similar to DsrC from dissimilatory sulfate- and sulfite reducers}

$d s r C$ encodes a soluble, cytoplasmic, 112 amino acid, $12.6 \mathrm{kDa}$ polypeptide with a theoretical isoelectric point of $\mathrm{pH} 4.97$. A homology search identified a significant degree of sequence identity with the $d s v(r) C$ gene products of Desulfovibrio vulgaris (Karkhoff-Schweizer et al., 1993), Pyrobaculum islandicum (Molitor et al., 1998) and A. fulgidus (Klenk et al., 1997) and to the products of the potential $y c c K$ genes from $E$. coli and $H$. influenzae (Table 2). A conspicuously high sequence similarity is found at the $\mathrm{C}$ terminus of these proteins (Fig. 2b). The strict conservation of a single cysteine residue in this region may hint at a catalytic function of DsrC in the metabolism of sulfur compounds. The $d s v C$-encoded gene product is co-purified with the dissimilatory sulfite reductases from some sulfate-reducing bacteria (Pierik et al., 1992; Arendsen et al., 1993; Steuber et al., 1995). For Desulfovibrio desulfuricans, a possible function of DsrC in thiosulfate and trithionate reduction has been pointed out (J. Steuber, personal communication, cited in Voordouw, 1995).

\section{dsr $M$ exhibits similarity to membrane-bound $b$-type cytochromes}

DsrM is deduced to be a protein of 243 amino acids with a molecular mass of $27.9 \mathrm{kDa}$ and a pI of $9 \cdot 85$. As shown in Table 2, optimum sequence similarity is shared with 
Table 2. Amino acid sequence similarity of $D s r E,-F,-H,-C,-M$ and $-K$ to other proteins

Up to a threshold of $1 \times 10^{-3}$ for the $P$-value, the seven best matches obtained with the $\Psi$-BLAST program are shown.

\begin{tabular}{|c|c|c|c|c|c|}
\hline Dsr protein & Organism & Gene & Function & $P$-value* & Accession no. \\
\hline DsrE & $\begin{array}{l}\text { E. coli } \\
\text { H. influenzae } \\
\text { Mb. thermoautotrophicum }\end{array}$ & $\begin{array}{l}y b e N \\
\text { HIO576 } \\
\text { MTH1357 }\end{array}$ & $\begin{array}{l}\text { Hypothetical } 13.6 \mathrm{kDa} \text { protein } \\
\text { Hypothetical protein } \\
\text { Conserved protein }\end{array}$ & $\begin{array}{l}1 \times 10^{-26} \\
3 \times 10^{-18} \\
5 \times 10^{-4}\end{array}$ & $\begin{array}{l}\text { sp P45532 } \\
\text { sp P44762 } \\
\text { gb AE000898 }\end{array}$ \\
\hline DsrF & $\begin{array}{l}\text { E. coli } \\
\text { H. influenzae } \\
\text { Mb. thermoautotrophicum }\end{array}$ & $\begin{array}{l}y b e M \\
\text { HI0576.1 } \\
\text { MTH1358 }\end{array}$ & $\begin{array}{l}\text { Hypothetical } 13.0 \mathrm{kDa} \text { protein } \\
\text { Hypothetical protein } \\
\text { Conserved protein }\end{array}$ & $\begin{array}{l}8 \times 10^{-9} \\
2 \times 10^{-7} \\
1 \times 10^{-5}\end{array}$ & $\begin{array}{l}\text { sp P45531 } \\
\text { gb U32739 } \\
\text { gb AE000898 }\end{array}$ \\
\hline DsrH & $\begin{array}{l}\text { E. coli } \\
\text { Mb. thermoautotrophicum }\end{array}$ & $\begin{array}{l}y h e L \\
\text { MTH1360 }\end{array}$ & $\begin{array}{l}\text { Hypothetical } 10.7 \mathrm{kDa} \text { protein } \\
\text { Conserved protein }\end{array}$ & $\begin{array}{l}2 \times 10^{-8} \\
3 \times 10^{-3}\end{array}$ & $\begin{array}{l}\text { gb U18997 } \\
\text { gb AE000898 }\end{array}$ \\
\hline \multirow[t]{2}{*}{ DsrC } & $\begin{array}{l}\text { E. coli } \\
\text { H. influenzae } \\
\text { A. fulgidus }\end{array}$ & $\begin{array}{l}y c c K \\
y c c K \\
d s v \mathrm{C}\end{array}$ & $\begin{array}{l}\text { Hypothetical protein } \\
\text { Hypothetical protein HI } 1371 \\
\text { Homologue of D. vulgaris } \\
\text { DsvC }\end{array}$ & $\begin{array}{l}2 \times 10^{-28} \\
2 \times 10^{-27} \\
2 \times 10^{-26}\end{array}$ & $\begin{array}{l}\text { gb AE000199 } \\
\text { sp P45184 } \\
\text { gb AE000951 }\end{array}$ \\
\hline & P. islandicum & $d s \nu C$ & $\begin{array}{l}\text { Proposed } \gamma \text { subunit of } \\
\text { dissimilatory sulfite reductase } \\
12 \cdot 7 \mathrm{kDa} \text { protein in } d s r \text { operon }\end{array}$ & $7 \times 10^{-19}$ & sp P45573 \\
\hline \multirow[t]{7}{*}{ DsrM } & A. fulgidus & AF0501 & $\begin{array}{l}\text { Putative } \gamma \text { subunit of nitrate } \\
\text { reductase }\end{array}$ & $3 \times 10^{-34}$ & gb AE001069 \\
\hline & A. fulgidus & AF0546 & $\begin{array}{l}\text { Putative } \gamma \text { subunit of nitrate } \\
\text { reductase }\end{array}$ & $2 \times 10^{-13}$ & gb AE001066 \\
\hline & A. fulgidus & AF0545 & Hypothetical protein & $4 \times 10^{-7}$ & gb AE001067 \\
\hline & E. coli & narl & $\gamma$ subunit of nitrate reductase 1 & $6 \times 10^{-6}$ & sp P11350 \\
\hline & Th. thermophilus & $n a r V$ & $\gamma$ subunit of nitrate reductase 2 & $2 \times 10^{-4}$ & gb Y10124 \\
\hline & Ms. barkeri & $b d r E$ & $\begin{array}{l}29.7 \mathrm{kDa} \text { subunit, } \\
\text { heterodisulfide reductase }\end{array}$ & $2 \times 10^{-4}$ & gb Y09870 \\
\hline & D. vulgaris & $b m c 5$ & $\begin{array}{l}25.3 \mathrm{kDa} \text { protein in } b m c \\
\text { operon }\end{array}$ & $8 \times 10^{-3}$ & sp P33392 \\
\hline \multirow[t]{7}{*}{ DsrK } & A. fulgidus & AF0502 & $\begin{array}{l}\text { Heterodisulfide reductase, } \\
\text { putative subunit } \mathrm{D}\end{array}$ & $1 \times 10^{-105}$ & gb AE001069 \\
\hline & A. fulgidus & AF0547 & Iron-sulfur binding reductase & $1 \times 10^{-65}$ & gb AE001066 \\
\hline & A. fulgidus & AF0543 & Conserved hypothetical protein & $4 \times 10^{-47}$ & gb AE001067 \\
\hline & A. fulgidus & AF0544 & Conserved hypothetical protein & $2 \times 10^{-35}$ & gb AE001067 \\
\hline & D. vulgaris & $b m c 6$ & $\begin{array}{l}52.7 \mathrm{kDa} \text { protein in } \mathrm{bmc} \\
\text { operon }\end{array}$ & $2 \times 10^{-28}$ & sp P33393 \\
\hline & Ms. barkeri & $b d r D$ & $\begin{array}{l}46 \mathrm{kDa} \text { subunit, heterodisulfide } \\
\text { reductase }\end{array}$ & $3 \times 10^{-18}$ & gb Y09870 \\
\hline & A. fulgidus & AF0755 & $\begin{array}{l}\text { Putative heterodisulfide } \\
\text { reductase, subunits } E \text { and } D\end{array}$ & $5 \times 10^{-12}$ & AE001052 \\
\hline
\end{tabular}

*Derived from $\Psi$-BLAST score; $P$-value represents the probability that the observed similarity had occurred by chance. Low $P$-values indicate a high probability of two proteins being structurally related.

the cytochrome $b$ subunits of bacterial nitrate reductases, the haem- $b$-containing subunit HdrE of heterodisulfide reductase from the archaeon Methanosarcina barkeri (Künkel $e$ t al., 1997) and with predicted $b$-type cytochromes from the sulfate reducers $A$. fulgidus (Klenk et al., 1997) and D. vulgaris (Hmc5; Rossi et al., 1993). A hydropathy analysis (ISREC TMpred server; Hofman \& Stoffel, 1993) of DsrM indicates the presence of five potential membrane-spanning helices (Fig. 2c). The $\mathrm{N}$ terminus is predicted to be in the periplasm. Four of the seven histidine residues are part of transmembrane helices and are strictly conserved in the haem- $b$ - containing proteins similar to DsrM. These histidines have been proposed to ligate a low-potential haem $b_{\mathrm{L}}$ oriented towards the periplasmic side of the membrane and a high-potential haem $b_{\mathrm{H}}$ oriented towards the cytoplasm (Berks et al., 1995).

\section{dsrK encodes an iron-sulfur protein similar to heterodisulfide reductase}

The protein deduced from $d s r K$ is a soluble, cytoplasmic, 524 amino acid, $58.5 \mathrm{kDa}$ polypeptide with a $\mathrm{pI}$ of 4.7 . The polypeptide is similar to the catalytic subunit 
(a) CvDsrF 1 CvDsry 1 CvDsre 1

CvDsrF CvDsrH CvDsre

CvDsrF CvDsrH CvDsre
MSEVVKKFMYINRY AFMGTIYAWEALEVVLICAAFDQDVC-VLFIDDGTYQLTRGQDTKG

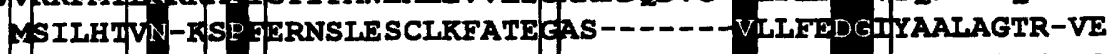

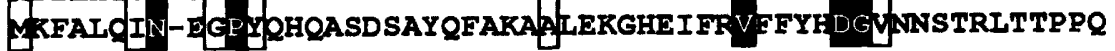

(b) CvDsrc ECY CCK HaeYcck AfDsvC DvDsvC PiDsrC

CvDsrC ECYCCK HaeYccK AfDsve DvDsvC PiDsrC

(c) CvDsrM EcNarI DvHme5

CrDsrM ECNarI DvHinc5

$\begin{array}{lr}\text { CvDsrM } & 114 \\ \text { ECNarI } & 97 \\ \text { DvHinc5 } & 120\end{array}$

CvDsry ECNarI DvHime5

172 157 174

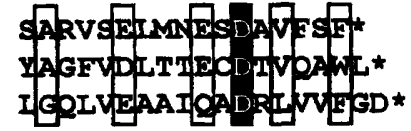

56
72
53
60
56
62

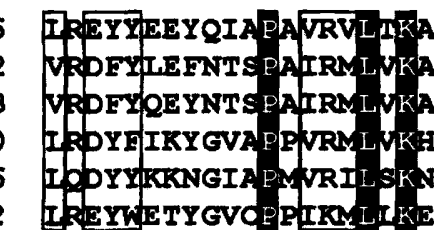
IRYMTTYG

\section{Helix a}

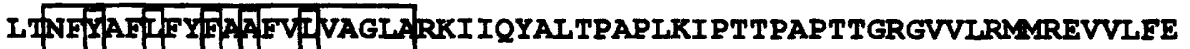
LNMDIFD IY DY IA GA WEL I GSWLRYDYGQY TWRAAS-_... GEMI AASTIVIDEGI IARVIK YIRGLDWRIDRVAYKPHLAIGLQGAVQSALKWLVPFGT$\nabla$ Helix b $\nabla$

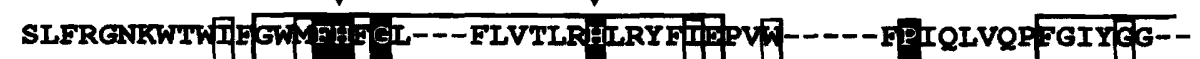
SQMLDRRGMI SNI FHI I---LGIFVGHFFGN

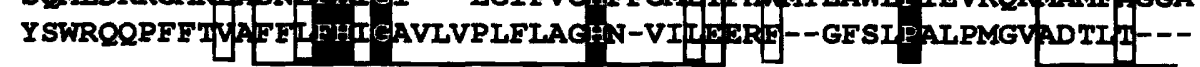

Helix c Helix d

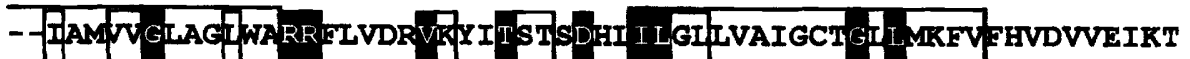

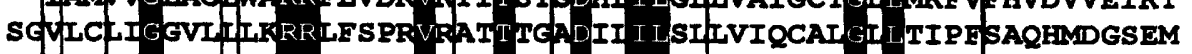

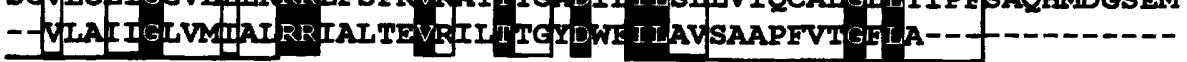

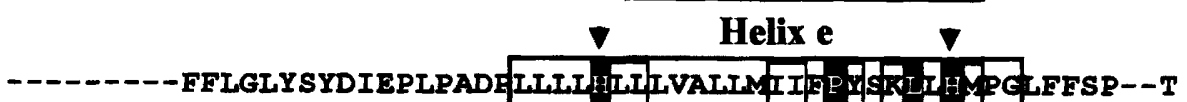
MKVEWAQSVVTFHGGASQHLDGVA IFRIHLVLGMTLFLIP -

$\begin{array}{lll}\text { CVDsrM } & 221 & \text { RNQVDNPREQRHIAPWARKLEQS* } \\ \text { ECNarI } & 215 & \text { TRKYQLVRARH* } \\ \text { DvHmC5 } & 208 & \text { GMYAIKRGGA* }\end{array}$

Fig. 2. For legend see facing page. 


$\begin{array}{ll}\text { CvDsrK } & 1 \\ \text { DvHimc6 } & 1 \\ \text { MsbHdrD } & 1\end{array}$

CvDsrR

Dvimc6

MsbHdrD

CvDsrK

Dvime6

MsbHdrD

CvDsrR

DvHimc6

MsbHdrD

CvDsrR

DvHinc6

MsbHdrD

CvDsrK

Dvime6

MsbHdrD

CrDsrR

Dvimc6

MsbHdrD

CrDsrK

Dvime6

MsbHdrD

173

149

118

233

208

176

293

266

226

352

323

280

412

374

330
MAKATFEVPELTQYTEVPSVTPGAMAHSAPFKSKEDFQTPLGFPG--ELVDDWQTKA IDK
MPEGKFCNRKPVNTEEDLKALLGDKGGAQYYKEMEELEVD
MAKRTPSI IT

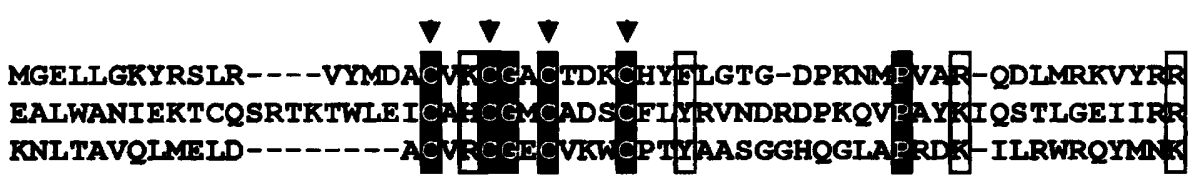

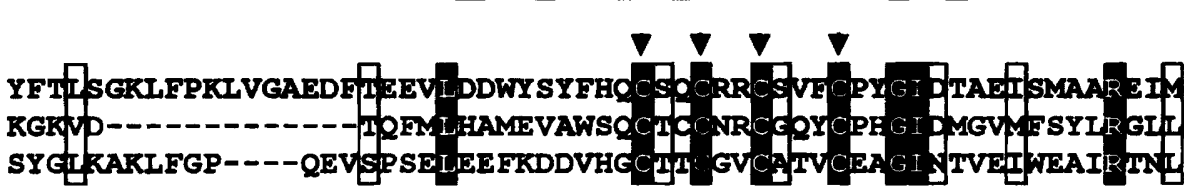

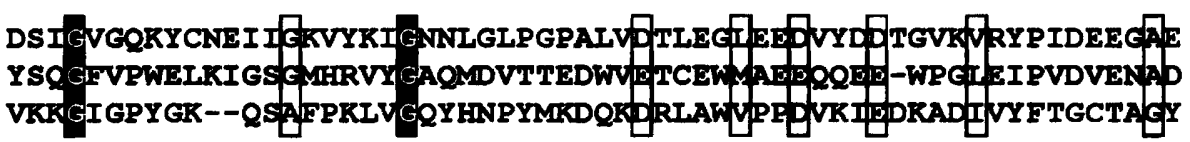

ILLVTPSADFFAEPHVDGTHGYGKOFHEAGVSWTISSYASEA PNFGMFIGSYDNMRRVAQ IMYVLNAREPKHYP--ED WAEAA I FHIAGEN WTV SEGWEO ISI.AMFAGDWAACKMQVE NQLALAFATSRVLN---K GIKFA LLGEE--EWCCES----DLIRTGQVHVDDVAREIA

CvDsrK
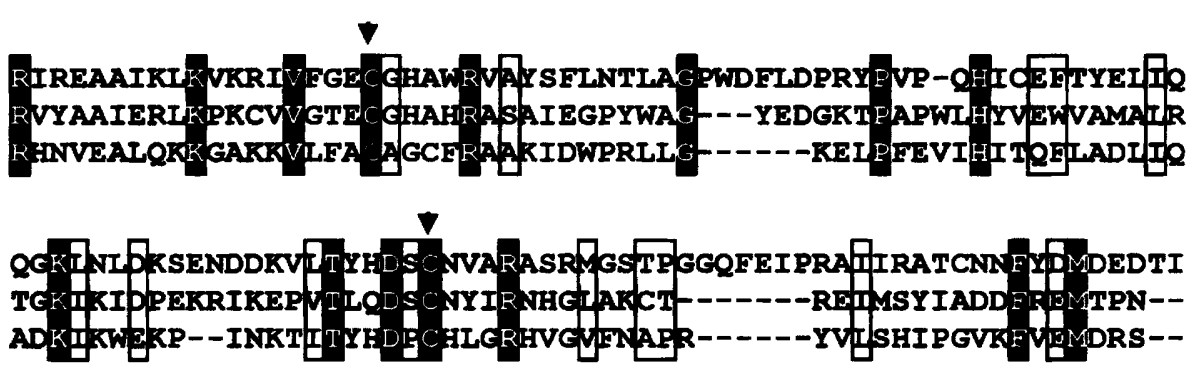

Dvinc6

472

431

MsbHarD

385

Fig. 2. Alignment of amino acid sequences of proteins encoded in the $C$. vinosum $d s r$ locus with similar polypeptides. The alignments were produced using the program CLUSTAL W (Higgins \& Sharp, 1989) using the Mutation Data Matrix (Dayhoff et al., 1978; George et al., 1990). In all alignments strictly conserved residues are printed white on black and similar amino acids (similarity groups after Dayhoff et al., 1978) are boxed. (a) Alignment of DsrF, DsrH and DsrE. (b) Alignment of DsrC with similar proteins from $E$. coli (EC), $H$. influenzae (Hae), A. fulgidus (Af), $D$. vulgaris (Dv) and $P$. islandicum (Pi). (c) Alignment of DsrM with the $\gamma$ subunit of $E$. coli nitrate reductase (EcNarl) and the $h m c 5$-encoded polypeptide from D. vulgaris (DvHmc5). Potential membrane-spanning hydrophobic sequences (helices a-e) are boxed. Potential haem-b-ligating histidine residues are highlighted by arrows. This alignment was done such that the hydrophobic stretches were first aligned and fixed. (d) Alignment of Dsrk with the $D$. vulgaris hmc6-encoded protein (DvHmc6) and the HdrD subunit of Ms. barkeri heterodisulfide reductase (MsbHdrD). Strictly conserved cysteine residues are highlighted by arrows.

HdrD of heterodisulfide reductase from Ms. barkeri (Künkel et al., 1997), to the $b m c 6$ gene product from $D$. vulgaris (Rossi et al., 1993) and to several hypothetical proteins from A. fulgidus (Table 2, Fig. 2d). Like dsrM and $d s r K$ in C. vinosum, $h d r E / h d r D, h m c 5 / h m c 6$ and the respective $A$. fulgidus genes are juxtapositioned. The
N-terminal parts of DsrK, HdrD and Hmc6 have similarity to $\mathrm{HdrC}$ of heterodisulfide reductase from Mb. thermoautotrophicum (Hedderich et al., 1994) while their $\mathrm{C}$ termini are similar to the $\mathrm{HdrB}$ subunit of the latter enzyme. In methanogenic archaea, heterodisulfide reductases catalyse the reduction of 


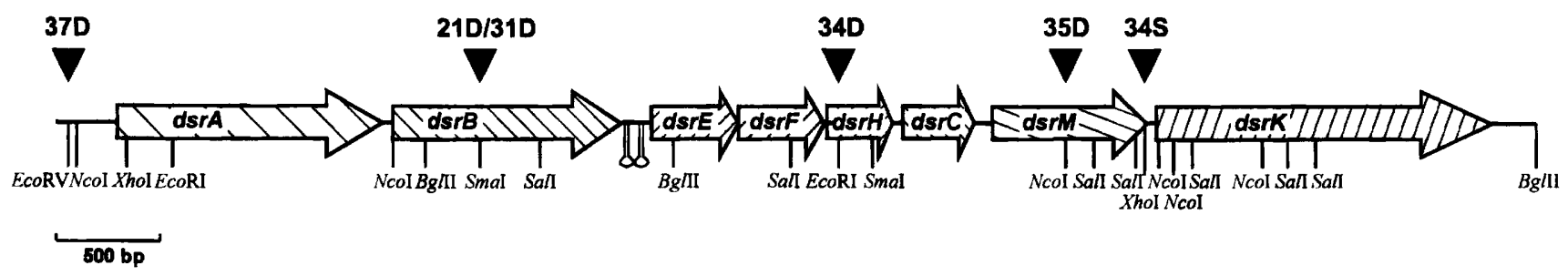

Fig. 3. Schematic representation of the $d s r$ locus in $C$. vinosum. The positions of insertion sites of the $\mathrm{Km} \Omega$ cartridge in the C. vinosum single-crossover mutant 345 and the double-crossover mutants 37D, 21D/31D, 34D and 35D are indicated.

(a)

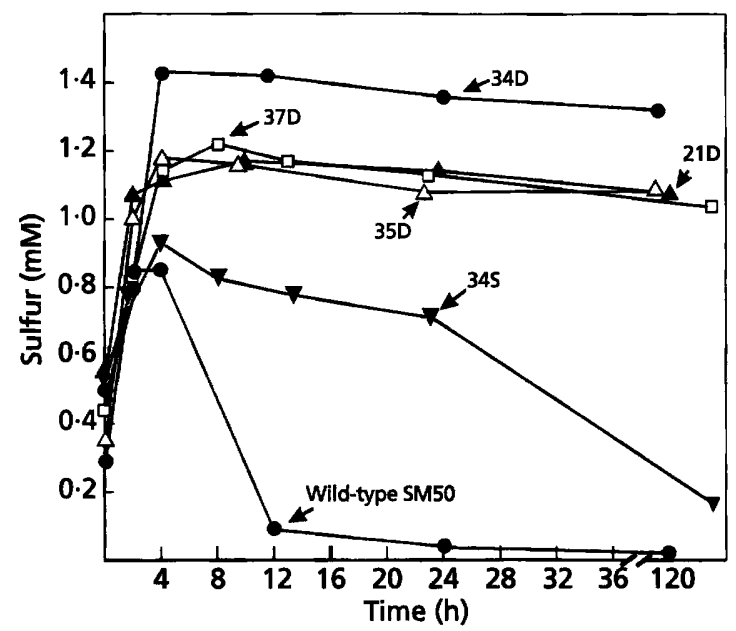

(b)

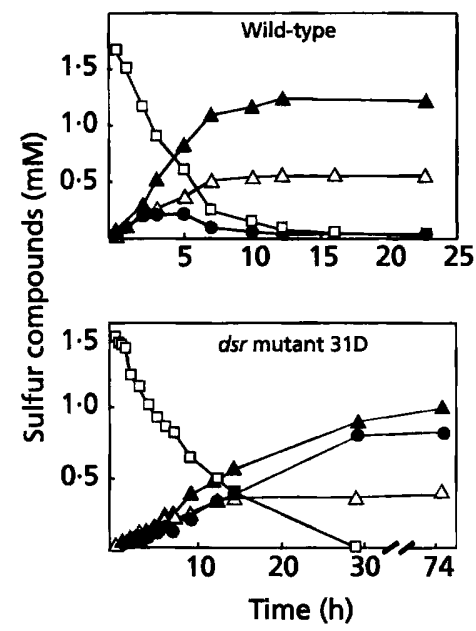

Fig. 4. Sulfur accumulation and oxidation by the wild-type and $d s r$ mutants during photolithoautotrophic growth on sulfide (a) and thiosulfate (b). (a) Sulfur content of cultures of the wild-type and dsr mutants. The representative experiments shown were performed in completely filled $250 \mathrm{ml}$ glass bottles on mineral salts medium with an initial sulfide concentration of $5 \mathrm{mM}$. Sulfide is not completely recovered as sulfur due to loss of gaseous $\mathrm{H}_{2} \mathrm{~S}$ during sampling. Sulfide and sulfate concentrations were also measured but are not shown for clarity. Note that the time axis is not to scale between 36 and $120 \mathrm{~h}$. The protein content of the cultures was $120.0,76 \cdot 3,132.5,190.0,95.0$ and $65.0 \mu \mathrm{g} \mathrm{m} \mathbf{l}^{-1}$ for SM50, 37D, 21D, 34D, 35D and 34S, respectively. (b) Thiosulfate oxidation by the wild-type compared to thiosulfate utilization by mutant 31D. The representative experiments shown were performed in pH-controlled fermenter cultures as described by Dahl (1996). $Q$, Sulfur; $\square$, thiosulfate; $\Delta$, sulfate; $\triangle$, tetrathionate. Note that the time axis is not to scale between 30 and $74 \mathrm{~h}$ for mutant 31D.

Co-M-S-S-B-Co to reduced coenzyme $M$ and reduced coenzyme B (Künkel et al., 1997). The related thiol: fumarate reductases from $M b$. thermoautotrophicum and $M c$. jannaschii catalyse the reduction of fumarate with coenzymes $M$ and $B$ as electron donors (Bobik \& Wolfe, 1989; Bult et al., 1996; Künkel et al., 1997). The $\mathrm{N}$-terminal parts of the proteins similar to DsrK contain two copies of the sequence motif $\mathrm{CX}_{2} \mathrm{CX}_{2} \mathrm{CX}_{3} \mathrm{C}$ indicating the presence of two [4Fe-4S] clusters. In pyridinenucleotide-dependent thioredoxin reductases the two redox-active cysteine residues are separated by two amino acids in the sequence VXXCATCD (Russel \& Model, 1988; Lübbers \& Andreesen, 1993; Cohen et al., 1993; Jacquot et al., 1994). A comparable arrangement is found near the $\mathrm{C}$ terminus of DsrK, HdrD and Hmc6 (Fig. 2d) and could constitute the redox-active disulfide of these proteins. It is furthermore interesting to note that amino acids $188-214$ of C. vinosum DsrK share similarity with amino acids $7-33$ of glycine reductase selenoprotein PA from Eubacterium acidaminophilum and several Clostridium species. After its oxidation during the reductive deamination of glycine this protein is re-reduced by the thioredoxin system (Dietrichs et al., 1991).

\section{Construction and characterization of $C$. vinosum strains with mutations in dsr genes}

C. vinosum strains with defined mutations in the $d s r$ genes were constructed by insertion of a kanamycin $\Omega$ interposon (Fellay et al., 1987) (Fig. 3), which leads to premature termination of transcription of the affected gene and downstream genes in the same transcription unit. As expected for a classical purple sulfur bacterium (Brune, 1989), the wild-type oxidized sulfide first to intracellular sulfur, which was further oxidized to sulfate when sulfide was depleted. Mutants 37D, 31D, $34 \mathrm{D}$ and $35 \mathrm{D}$, with polar mutations upstream of $d s r A$, 


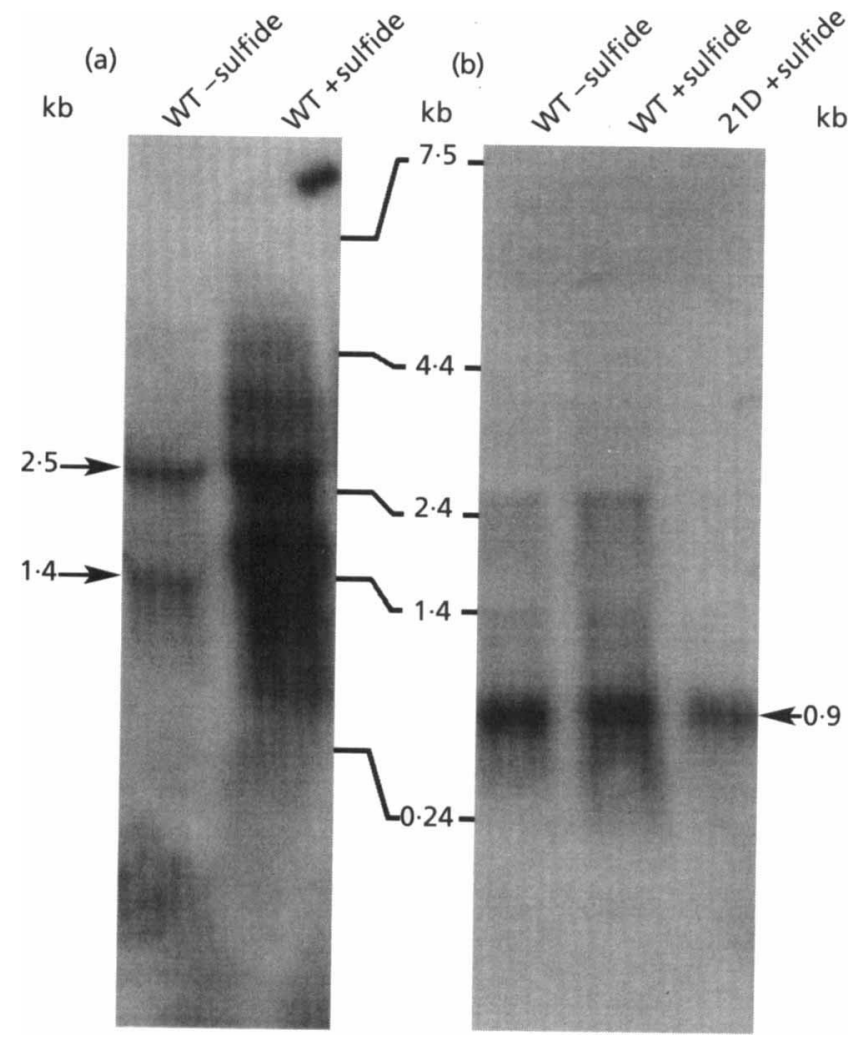

Fig. 5. Northern blot hybridizations performed with a dsrAB (a) and a dsrC (b) probe. Exactly $10 \mu \mathrm{g}$ total RNA was loaded per lane. RNA was isolated from cells growing exponentially under photoheterotrophic conditions on malate. Where indicated $2.25 \mathrm{mM}$ and $4.2 \mathrm{mM}$ sulfide was added to the cultures of the wild-type (WT) and mutant 21D, respectively. In these cases, RNA was isolated when sulfide was depleted from the cultures.

and in $d s r B, d s r H$ and $d s r M$, respectively, oxidized sulfide to sulfur with rates comparable to those of the wild-type; however, the ability of the cells to oxidize intracellular sulfur was completely abolished (Fig. 4a). Mutant 345 exhibited a greatly reduced rate of intracellular sulfur oxidation. This mutant arose by single crossover recombination with plasmid pAP34 and should be able to form DsrA, $-\mathrm{B},-\mathrm{E},-\mathrm{F},-\mathrm{H}$ and $-\mathrm{C}$. The very $\mathrm{C}$-terminal end of $\mathrm{DsrM}$ is altered probably not changing the protein's properties, and DsrK cannot be formed unless the respective gene is transcribed from a promoter downstream of the $\mathrm{Km} \Omega$ insertion site in the second, inactivated copy of $d s r H$. The effect of a mutation in the $d s r$ genes on thiosulfate oxidation is illustrated for mutant 31D in Fig. 4(b). Typical for C. vinosum at $\mathrm{pH} 7 \cdot 0$ (Smith, 1966), the wild-type and the mutant oxidized part of the thiosulfate to tetrathionate, which was not further metabolized. The other part of the thiosulfate is split to sulfide and sulfite. Whilst sulfite is directly oxidized to sulfate, sulfide first appears as intracellular sulfur and is then oxidized to sulfate (Trüper \& Fischer, 1982; Brune, 1989, 1995a). The wildtype showed this typical oxidation pattern, whereas the mutant accumulated sulfur but was not able to further oxidize it. Sulfite oxidation was not affected in the $d s r$ mutants (not shown). All mutants also grew normally under photoorganoheterotrophic conditions (not shown).

\section{Sulfide induction experiments and mRNA analysis}

For C. vinosum SM50 (wild-type), two different distinct mRNA bands of 2.5 and $1.4 \mathrm{~kb}$ were detected with a dsrAB (nucleotides 1298-2500) probe (Fig. 5). Distinct bands over $2.6 \mathrm{~kb}$ that would have indicated a common transcript $d s r A B E F H C M K$ were not detected, even after prolonged film exposure. The formation of a common transcript cannot, however, be excluded, because such a long mRNA may be very unstable. As hybridization with the $d s r A B$ probe led to the detection of a smear reaching up to a size of approximately $6.0 \mathrm{~kb}$, degradation of RNA may indeed have occurred and the bands at $2.5 \mathrm{~kb}$ and $1.4 \mathrm{~kb}$ could represent specific or even unspecific degradation products. Nevertheless, hybridization with the $d s r A B$ probe yielded important information when RNA from photoheterotrophically grown and from sulfide-induced cells was compared. The latter cells were harvested when they had just begun to oxidize stored sulfur. Photoheterotrophically growing C. vinosum contained far lesser amounts of mRNA hybridizing with $d s r A B$ than sulfur-oxidizing cells (Fig. $5)$. The finding that $d s r A B$ are transcribed at a low level in the absence of reduced sulfur compounds is not in agreement with earlier results of Schedel et al. (1979) who were unable to detect sulfite reductase in malategrown cells. The level of sulfite reductase in these cells might, however, have been below the detection limit or further regulation mechanisms may work at the posttranscriptional level.

A $d s r C$ probe (nucleotides $4086-4401$ ) reacted with an mRNA of approximately $0.9 \mathrm{~kb}$. In addition, the wildtype showed a faint smear with a maximum size of $2.5 \mathrm{~kb}$ and very faint signals resulting from RNAs of even bigger sizes. In contrast to the hybridizations with $d s r A B$, the intensity of the signal was independent of the presence of sulfide in the medium. Mutant 21D contained the same $0.9 \mathrm{~kb}$ band that was found for the wildtype (Fig. 5).

\section{DISCUSSION}

The nucleotide sequence of the C. vinosum dsr locus at first sight suggests that the $d s r A B E F H C M K$ genes form a single transcriptional unit. A sequence resembling $\sigma^{70}$ promoters was found upstream of $d s r A$ and the following genes are separated by short intergenic sequences in which further putative promoter sequences are not apparent. A distinct transcript long enough to cover the whole sequenced $d s r$ region was, however, not detected and mRNAs of different sizes reacted with $\operatorname{ds} A B$ and $d s r C$ probes. As the occurrence of these mRNAs is not co-ordinately regulated in $C$. vinosum, they cannot result from the degradation of a common, longer transcript covering $d s r A B$ as well as $d s r C$ unless the 


\section{Periplasm}

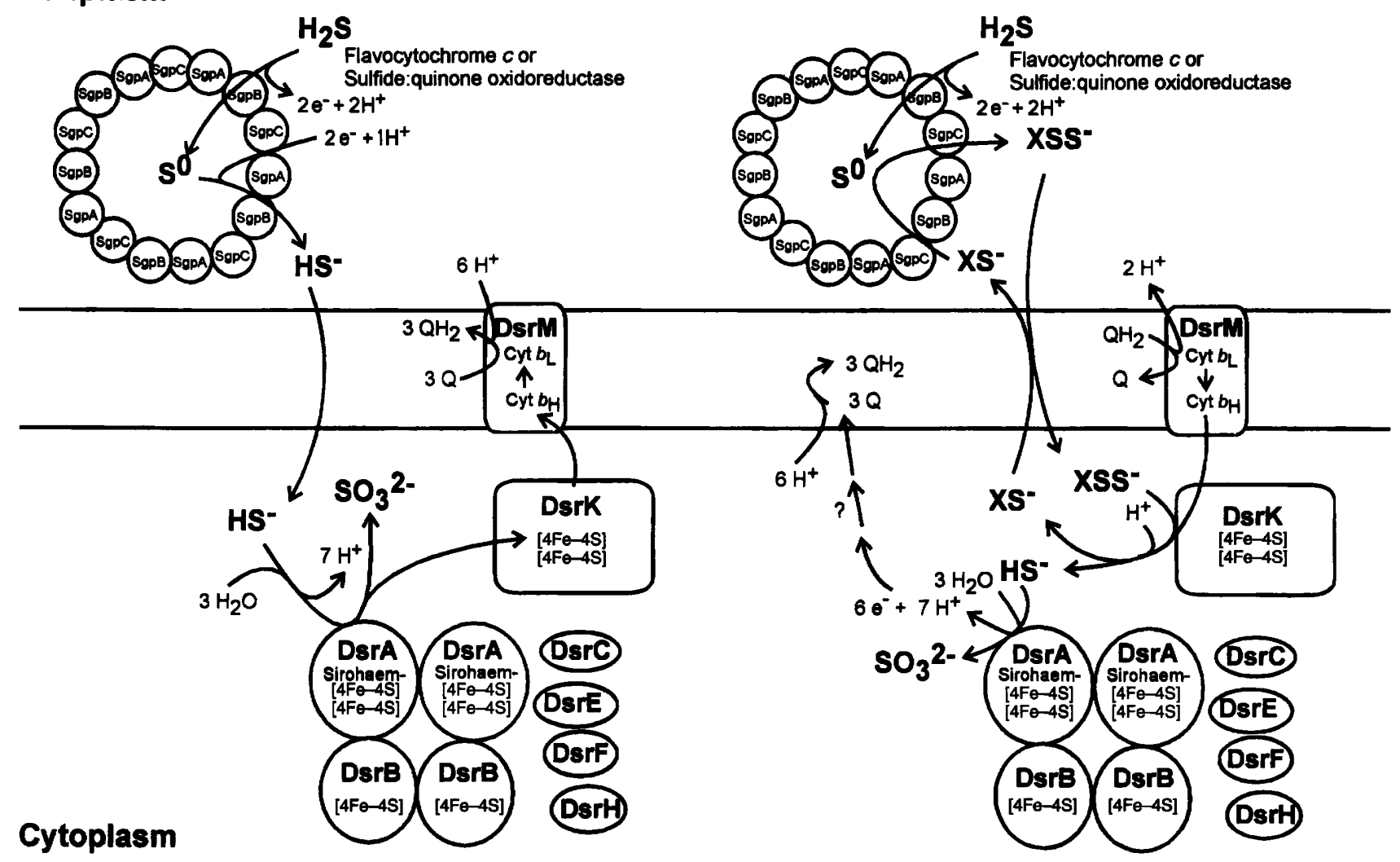

Fig. 6. Models for sulfur oxidation in $C$. vinosum and involvement of the proteins encoded in the $d s r$ locus. A sulfur globule is schematically represented with its envelope consisting of the three different proteins SgpA, SgpB and SgpC (Brune, 1995b; Pattaragulwanit et al., 1998). By analogy to the enzymes from sulfate-reducers, C. vinosum sirohaem sulfite reductase is depicted as an $\alpha_{2} \beta_{2}$-structured protein binding two sirohaem prosthetic groups. Model $\mathrm{A}$ allows electron flow from cytoplasmic sulfite reductase to the integral membrane protein DsrM via the iron-sulfur protein DsrK. Model B proposes the shuttling of sulfur from the extracytoplasmic sulfur globule to the cytoplasm via a perthiol acting as a carrier molecule. DsrM and DsrK are involved in the regeneration of a thiol and sulfide from the hypothetical perthiol in the cytoplasm.

stability of the processed transcripts is different under different growth conditions. As the same $0.9 \mathrm{~kb}$ RNA reacts with $d s r C$ in the wild-type and in mutant 21D, we conclude that transcription of the $d s r$ genes can start at at least two different promoters, one of which must be located downstream of $d s r B$, the insertion site of the interposon in mutant 21D (Fig. 2). In this respect it is interesting to note that the sequence between $d s r H$ and $d s r C$ has a conspicuously low G $+C$ content of only $35.7 \mathrm{~mol} \%$, which may indicate a function in transcription initiation or regulation. The smear of longer RNAs detected in the wild-type with the $d s r C$ and the $d s r A B$ probes indicates that transcripts covering the whole sequenced $d s r$ locus may in addition be formed in vivo. The $2.5 \mathrm{~kb}$ mRNA detected with $d s r A B$ represents the length expected for a transcript originating from the putative promoter upstream of $d s r A$ and ending at the hairpin loop structures downstream of $d s r B$. A sequence conforming to the proposed consensus for RNase $E$ cleavage sites $(\mathrm{G} / \mathrm{A})^{\prime} \mathrm{A}^{\prime} \mathrm{TT}(\mathrm{A} / \mathrm{T})$ (Ehretsmann et al.,
1992) occurs immediately downstream of these inverted repeats (Fig. 1). It has been suggested that RNase E requires a hairpin loop structure in close proximity to its recognition site for maximal cleavage rates. Further experimentation is necessary to clarify whether the $2.5 \mathrm{~kb}$ transcript arises from transcription termination at the hairpin loops or from degradation of a longer transcript.

Strains with interposon mutations in the $d s r$ genes grew normally under photoheterotrophic conditions. The oxidation of sulfide to sulfur, of thiosulfate to tetrathionate, of sulfite to sulfate, and the initial splitting reaction during thiosulfate oxidation to sulfate were not affected in the $d s r$ mutants but all mutant strains showed a reproducible inability to oxidize intracellularly stored sulfur under photolithoautotrophic growth conditions. This provides strong evidence for the participation of the dsrABEFHCMK-encoded proteins in sulfur oxidation. As already discussed, Northern hybridizations 
with the $d s r C$ probe indicate that transcription of $d s r$ genes can start at (a) promoter(s) downstream of $d s r B$. The failure of mutant $21 \mathrm{D}$ to oxidize sulfur can, therefore, be attributed to the lack of sulfite reductase and is not due to a polar effect of the interposon in $d s r B$ on the downstream genes. Mutant 37D carries an insertion $20 \mathrm{bp}$ upstream of the putative promoter sequence upstream of $d s r A$. Although the putative promoter is intact, this mutant is not able to oxidize internal sulfur. This could either be explained by the fact that the true promoter lies upstream of the $\mathrm{Km}^{\mathrm{r}}$ insertion site or be due to the interruption of a region essential for transcriptional regulation. In future, construction of strains with mutations upstream and downstream of the sequenced $d s r$ genes will show whether further proteins involved in sulfur oxidation are encoded in this region.

Amino acid sequence analysis suggests that the dsrABEFHCMK gene products are all cytoplasmic or membrane-bound. The sulfur globules of C. vinosum are, however, located extracytoplasmically (Pattaragulwanit et al., 1998), implying that sulfur in some way has to be transported across the membrane - probably in a reductively activated form - before it can serve as a substrate for the $d s r$-encoded proteins. The idea that sulfur has to be reductively activated before further oxidation is supported by the finding of Hurlbert (1968) that thiol-binding reagents like $N$-ethylmaleimide inhibit sulfur oxidation in C. vinosum.

As pointed out above, DsrM is similar to the membranebound haem- $b$-binding $\gamma$ subunits of dissimilatory nitrate reductases, the direct electron donor of which is ubiquinol or menaquinol (Craske \& Ferguson, 1986; Berks et al., 1995). In the course of quinol oxidation, protons are released to the periplasm by these polypeptides. In C. vinosum, DsrM could either function as a quinol oxidase like the nitrate reductase $\gamma$ subunits or operate in the reverse direction as a quinone reductase. For both cases, models for the pathway of sulfur oxidation can be envisaged and are illustrated in Fig. 6 .

In model A it is assumed that extracytoplasmic sulfur is made available for cytoplasmic sulfite reductase by reduction to the level of sulfide which either diffuses into or is actively transported to the cytoplasm. The [4Fe-4S]-cluster-containing DsrK could function in electron transport from sulfite reductase to DsrM. DsrM could then feed these electrons into the photosynthetic electron transport chain. This speculation on the function of DsrM and DsrK was prompted by a proposal of Rossi et al. (1993) that the related proteins Hmc5 and Hmc6 function in the opposite direction in D. vulgaris, transferring electrons from periplasmic hydrogenase to the cytoplasmic sulfate-reducing enzymes. In strict analogy to the nitrate reductase $\gamma$ subunits, DsrM working as quinone reductase would take up protons for $\mathrm{QH}_{2}$ generation from the periplasm, i.e. it would work against the photosynthetic $\Delta p$. Furthermore, electron transfer from cytochrome $b_{\mathrm{H}}$ to cytochrome $b_{\mathrm{L}}$ would have to be proposed. So far, model A does not consider the significant similarity of DsrK to archaeal heterodisulfide reductases, which implies a function in the oxidation of two thiols or the reduction of a di- or persulfide. One possibility is that the electrons from sulfide oxidation are used to reduce a hypothetical disulfide and that the resulting two thiols are oxidized by DsrK, regenerating the disulfide. DsrC contains a single conserved cysteine residue which could play a role in such a scenario. An additional weakness of model A is that it does not explain how the reductive activation of extracytoplasmic sulfur is achieved. Furthermore, it is unlikely that sulfur is indeed reduced back to hydrogen sulfide. First, the problem arises as to how the cell would be able to prevent immediate reoxidation of periplasmically developing sulfide to sulfur. Second, it is difficult to explain why oxidation of sulfide to sulfite catalysed by sulfite reductase should not occur in parallel to sulfide oxidation resulting in sulfur globule formation. If the components and compounds involved in sulfur formation and those functioning in sulfur oxidation were different, the cell would be able to perform and regulate each step independently.

Model B in Fig. 6 takes these considerations into account and suggests that DsrK plays an indirect role in the reductive activation of the relatively inaccessible stored sulfur. DsrM could function as quinol oxidase and donate electrons to DsrK, which in turn could reduce a hypothetical disulfide. We have depicted the simplest case, i.e. that the disulfide is a perthiol which upon reduction yields a thiol and sulfide. Sulfide could then be directly oxidized by cytoplasmic sulfite reductase whilst the thiol could be transported to the extracytoplasmic space and nucleophilically attack sulfur, thereby regenerating the perthiol. After transport of this compound to the cytoplasm, the cycle could start again. This model is supported by findings of Bartsch et al. (1996) who reported that $C$. vinosum specifically accumulates the persulfide form of glutathione amide as well as three further as yet unidentified perthiols when growing photoautotrophically on sulfide. Bartsch et al. (1996) speculated that the observed perthiols could act as carrier molecules of sulfur to and from the sulfur globules. To our knowledge, information about transport of thiols and perthiols across membranes is not available for phototrophic bacteria, but such a transport is feasible and could be mediated by specialized transport proteins.

Working as a quinol oxidase, DsrM would extrude protons to the periplasm. When C. vinosum fixes $\mathrm{CO}_{2}$ in the presence of reduced sulfur compounds, photosynthetic electron flow can be considered essentially linear and the proposed system could contribute to $\Delta p$. On the other hand, a high $\Delta p$ generated by cyclic electron flow, especially under conditions where $\mathrm{CO}_{2}$ assimilation is limited, could exert a thermodynamic back pressure on the system and lower the rate of sulfur oxidation. Without knowledge about the pool sizes, redox potentials and regulation of the components involved in such a system, it is at present not possible to decide if it could function in vivo. Model B does not 
answer the question of how the electrons resulting from sulfide oxidation by sulfite reductase are fed into the electron transport chain.

In both models it remains unclear which reaction could yield the electrons for reductive activation of stored sulfur. Once sulfur oxidation gets started, the electrons could indirectly be supplied by the sulfite reductase reaction or by the further oxidation of sulfite to sulfate $\left(E_{0}^{\prime}=-516 \mathrm{mV}\right)$. The $M s$. barkeri heterodisulfide reductase and probably also $D$. vulgaris Hmc6 receive electrons from periplasmic hydrogenase. $b m c 5-$ and $b m c 6$-homologous genes are intercalated between the bupSL genes encoding the small and large subunits of the stable, constitutively expressed hydrogenase from Thiocapsa roseopersicina BBS (Rákhely et al., 1998). Taken together, these findings may point to a connection between sulfur metabolism and hydrogenase in purple sulfur bacteria. In these organisms, a function has not yet been assigned to hydrogenase (Albracht, 1994).

We are far from clearly understanding the functional mechanism of sulfur oxidation in phototrophic sulfur bacteria and much more work is needed to exactly define the structural and catalytic properties of the $d s r$-encoded polypeptides in $C$. vinosum. However, the results presented in this paper allowed important insights into the oxidation of intracellularly stored sulfur, a pathway that has so far been very difficult to approach experimentally. The presented hypotheses are speculative but should provide incentives for the design of further experiments to study this interesting pathway.

\section{ACKNOWLEDGEMENTS}

This work was supported by grant $\mathrm{Da}$ 351/1-1 from the Deutsche Forschungsgemeinschaft. Excellent technical assistance by Dorit Zischka is gratefully acknowledged. We are indebted to Hans G. Trüper, Daniel C. Brune and Werner Klipp for stimulating discussions. Thomas Brüser is gratefully acknowledged for helpful suggestions concerning model B. We thank Daniel Burdziak for help with DNA sequencing. A. S. Pott was supported by a scholarship of the Studienstiftung des Deutschen Volkes.

\section{REFERENCES}

Albracht, S. P. J. (1994). Nickel hydrogenases: in search of the active site. Biochim Biophys Acta 1188, 167-204.

Altschul, S. F., Gish, W., Miller, W., Myers, E. W. \& Lipman, D. J. (1997). Gapped BLAST and Psi-BLAST: a new generation of protein database search programs. Nucleic Acids Res 25, 3389-3402.

Arendsen, A. F., Verhagen, M. F. J. M., Wolbert, R. B. G., Pierik, A. J., Stams, A. J. M., Jetten, M. S. M. \& Hagen, W. R. (1993). The dissimilatory sulfite reductase from Desulfosarcina variabilis is a desulforubidin containing uncoupled metalated sirohemes and $S=9 / 2$ iron-sulfur clusters. Biochemistry 32, 10323-10330.

Ausubel, F. A., Brent, R., Kingston, R. E., Moore, D. D., Seidman,
J. G., Smith, J. A. \& Struhl, K. (1997). Current Protocols in Molecular Biology. New York: John Wiley.

Bartsch, R. G., Newton, G. L., Sherrill, C. \& Fahey, R. C. (1996). Glutathione amide and its perthiol in anacrobic sulfur bacteria. $J$ Bacteriol 178, 4742-4746.

Bazaral, M. \& Helinski, D. R. (1968). Circular DNA forms of colicinogenic factors E1, E2 and E3 from Escherichia coli. J Mol Biol 36, 185-194.

Berks, B. C., Page, M. D., Richardson, D. J., Reilly, A., Cavill, A., Outen, F. \& Ferguson, S. J. (1995). Sequence analysis of subunits of the membrane-bound nitrate reductase from a denitrifying bacterium: the integral membrane subunit provides a prototype for the dihaem electron-carrying arm of a redox loop. Mol Microbiol 15, 319-331.

Bobik, T. A. \& Wolfe, R. S. (1988). Physiological importance of the heterodisulfide of coenzyme $M$ and 7-mercaptoheptanoylthreonine phosphate in the reduction of carbon dioxide to methane in Methanobacterium. Proc Natl Acad Sci USA 85, $60-63$.

Brune, D. C. (1989). Sulfur oxidation by phototrophic bacteria. Biochim Biophys Acta 975, 189-221.

Brune, D. C. (1995a). Sulfur compounds as photosynthetic electron donors. In Anoxygenic Photosynthetic Bacteria, pp. 847-870. Edited by R. E. Blankenship, M. T. Madigan \& C. E. Bauer. Dordrecht: Kluwer.

Brune, D. C. (1995b). Isolation and characterization of sulfur globule proteins from Chromatium vinosum and Thiocapsa roseopersicina. Arch Microbiol 163, 391-399.

Bult, C. J., White, O., Olsen, G. J. \& 37 other authors (1996). Complete genome sequence of the methanogenic archaeon, Methanococcus jannaschii. Science 273, 1058-1073.

Chen, Z. W., Koh, M., van Driessche, G., van Beeumen, J. J., Bartsch, R. G., Meyer, T. E., Cusanovich, M. A. \& Mathews, F. S. (1994). The structure of flavocytochrome c sulfide dehydrogenase from a purple phototrophic bacterium. Science 266, 430-432.

Cohen, G., Yanko, M., Mislovati, M., Argaman, A., Schreiber, R., Av-Gay, Y. \& Aharonowitz, Y. (1993). Thioredoxin-thioredoxin reductase system of Streptomyces clavuligerus: sequences, expression and organization of the genes. J Bacteriol 175, 5159-5167.

Craske, A. L. \& Ferguson, S. J. (1986). The respiratory nitrate reductase of Paracoccus denitrificans. Molecular characterization and kinetic properties. Eur J Biochem 158, 429-436.

Dahl, C. (1996). Insertional gene inactivation in a phototrophic sulphur bacterium: APS-reductase-deficient mutants of Chromatium vinosum. Microbiology 142, 3363-3372.

Dahl, C. \& Truper, H. G. (1994). Enzymes of dissimilatory sulfide oxidation in phototrophic bacteria. Methods Enzymol 243, 400-421.

Dahl, C., Kredich, N. M., Deutzmann, R. \& Truper, H. G. (1993). Dissimilatory sulphite reductase from Archaeoglobus fulgidus: physico-chemical properties of the enzyme and cloning, sequencing and analysis of the reductase genes. $J$ Gen Microbiol 139, 1817-1828.

Dahl, C., Speich, N. \& Trüper, H. G. (1994). Enzymology and molecular biology of sulfate reduction in the extremely thermophilic archaeon Archaeoglobus fulgidus. Methods Enzymol 243, 331-349.

Dayhoff, M. O., Schwartz, R. M. \& Orcutt, B. C. (1978). A model of evolutionary change in proteins. In Atlas of Protein Sequence and Structure, pp. 345-352. Edited by M. O. Dayhoff. Washington, DC: National Biochemical Research Foundation. 
Dietrichs, D., Meyer, M., Rieth, M. \& Andreesen, J. R. (1991). Interaction of selenoprotein $P_{A}$ and the thioredoxin system, components of the NADPH-dependent reduction of glycine in Eubacterium acidaminophilum and Clostridium litoralis. $J$ Bacteriol 173, 5983-5991.

Dolata, M. M., van Beeumen, J. J., Ambler, R. P., Meyer, T. E. \& Cusanovich, M. A. (1993). Nucleotide sequence of the heme subunit of flavocytochrome $c$ from the purple phototrophic bacterium, Chromatium vinosum. A 2.6 kilobase pair DNA fragment contains two multiheme cytochromes, a flavoprotein, and a homolog of human ankyrin. J Biol Chem 268, 14426-14431.

Ehretsmann, C. P., Carpousis, A. J. \& Krisch, H. M. (1992). Specificity of Escherichia coli endoribonuclease $\mathrm{E}$ : in vivo and in vitro analysis of mutants in a bacteriophage T4 $\mathrm{mRNA}$ processing site. Genes Dev 6, 149-159.

Fellay, R., Frey, J. \& Krisch, H. M. (1987). Interposon mutagenesis of soil and water bacteria: a family of DNA fragments designed for in vivo insertional mutagenesis of Gram-negative bacteria. Gene 52, 147-154.

Fischer, U. (1989). Enzymatic steps in dissimilatory sulfur metabolism by whole cells of anoxyphotobacteria. In Biogenic Sulfur in the Environment, pp. 262-279. Edited by E. Saltzman \& W. Cooper. Washington, DC: American Chemical Society.

George, D. G., Barker, W. C. \& Hunt, L. T. (1990). Mutation data matrix and its uses. Methods Enzymol 183, 333-351.

Hanahan, D. (1983). Studies on transformation of Escherichia coli with plasmids. $J$ Mol Biol 166, 557-580.

Hedderich, R., Koch, J., Linder, D. \& Thauer, R. K. (1994). The heterodisulfide reductase from Methanobacterium thermoautotrophicum contains sequence motifs characteristic of pyridinenucleotide-dependent thioredoxin reductases. Eur J Biochem 225, 253-261.

Higgins, D. G. \& Sharp, P. M. (1989). Clustal: a package for performing multiple sequence alignment on a microcomputer. Gene 73, 237-244.

Hipp, W. M., Pott, A. S., Thum-Schmitz, N., Faath, I., Dahl, C. \& Trüper, H. G. (1997). Towards the phylogeny of APS reductases and sirohaem sulfite reductases in sulfate-reducing and sulfuroxidizing prokaryotes. Microbiology 143, 2891-2902.

Hofman, K. \& Stoffel, W. (1993). TMbase-a database of membrane spanning protein segments. Biol Chem Hoppe-Seyler 347, 166-171.

Hurlbert, R. E. (1968). Effect of thiol-binding reagents on the metabolism of Chromatium vinosum D. J Bacteriol 95, 1706-1712.

Jacquot, J. P., Rivera-Madrid, R., Marinho, P., Kollarova, M., Le Marechal, P., Miginiac-Maslow, M. \& Meyer, Y. (1994). Arabidopsis thaliana NADPH thioredoxin reductase cDNA characterization and expression of the recombinant protein in Escherichia coli. J Mol Biol 235, 1357-1363.

Karkhoff-Schweizer, R. R., Bruschi, M. \& Voordouw, G. (1993). Expression of the $\gamma$-subunit gene of desulfoviridin-type dissimilatory sulfite reductase and of the $\alpha$ - and $\beta$-subunit genes is not coordinately regulated. Eur J Biochem 211, 501-507.

Klenk, H.-P., Clayton, R. A., Tomb, J.-F. \& 48 other authors (1997). The complete genome sequence of the hyperthermophilic, sulphate-reducing archaeon Archaeoglobus fulgidus. Nature 390, 364-370.

Kunkel, A., Vaupel, M., Heim, S., Thauer, R. K. \& Hedderich, R. (1997). Heterodisulfide reductase from methanol-grown cells of
Methanosarcina barkeri is not a flavoenzyme. Eur J Biochem 244, 226-234.

Lisser, S. \& Margalit, H. (1993). Compilation of E. coli mRNA promoter sequences. Nucleic Acids Res 21, 1507-1516.

Lübbers, M. \& Andreesen, J. R. (1993). Components of glycine reductase from Eubacterium acidaminophilum. Cloning, sequencing and identification of the genes for thioredoxin reductase, thioredoxin and selenoprotein $\mathrm{P}_{\mathrm{A}^{*}}$. Eur J Biochem 217, 791-798.

Molitor, M., Dahl, C., Molitor, I., Schafer, U., Speich, N., Huber, R., Deutzmann, R. \& Trüper, H. G. (1998). A dissimilatory sirohaemsulfite reductase-type protein from the hyperthermophilic archaeon Pyrobaculum islandicum. Microbiology 144, 529-541.

Pattaragulwanit, K. \& Dahl, C. (1995). Development of a genetic system for a purple sulfur bacterium : conjugative plasmid transfer in Chromatium vinosum. Arch Microbiol 164, 217-222.

Pattaragulwanit, K., Brune, D. C., Truper, H. G. \& Dahl, C. (1998). Molecular genetic evidence for extracytoplasmic localization of sulfur globules in Chromatium vinosum. Arch Microbiol (in press).

Pfennig, N. \& Trüper, H. G. (1989). Anoxygenic phototrophic bacteria. In Bergey's Manual of Systematic Bacteriology, vol. 3, pp. 1635-1653. Edited by J. T. Staley, M. P. Bryant, N. Pfennig \& J. G. Holt. Baltimore: Williams \& Wilkins.

Pierik, A. J., Duyvis, M. G., van Helvoort, J. M. L. M., Wolbert, R. B. G. \& Hagen, W. R. (1992). The third subunit of desulfoviridin-type dissimilatory sulfite reductases. Eur $J$ Biochem 205, 111-115.

Rákhely, G., Colbeau, A., Garin, J., Vignais, P. N. \& Kovács, K. L. (1998). Unusual gene organization of HydSL, the stable [NiFe]hydrogenase in the photosynthetic bacterium Thiocapsa roseopersicina. J Bacteriol 180, 1460-1465.

Reynolds, R., Bermudez-Cruz, R. M. \& Chamberlin, M. J. (1992). Parameters affecting transcription termination by Escherichia coli RNA. I. Analysis of 13 rho-independent terminators. $J \mathrm{Mol} \mathrm{Biol}$ 224, 31-51.

Rossi, M., Pollock, B. R., Reiji, M. W., Keon, R. G., Fu, R. \& Voordouw, G. (1993). The bmc operon of Desulfovibrio vulgaris subsp. vulgaris Hildenborough encodes a potential transmembrane redox protein complex. J Bacteriol 175, 4699-4711.

Russel, M. \& Model, P. (1988). Sequence of thioredoxin reductase from Escherichia coli. Relationship to other flavoprotein disulfide oxidoreductases. J Biol Chem 263, 9015-9019.

Sambrook, J., Fritsch, E. F. \& Maniatis, T. (1989). Molecular Cloning: a Laboratory Manual, 2nd edn. Cold Spring Harbor, NY: Cold Spring Harbor Laboratory.

Schedel, M., Vanselow, M. \& Truper, H. G. (1979). Siroheme sulfite reductase from Chromatium vinosum. Purification and investigation of some of its molecular and catalytic properties. Arch Microbiol 121, 29-36.

Simon, R., Priefer, U. \& Püler, A. (1983). A broad host range mobilization system for in vivo genetic engineering: transposon mutagenesis in gram negative bacteria. Bio/Technology 1, 784-791.

Smith, A. J. (1966). The role of tetrathionate in the oxidation of thiosulphate by Chromatium sp. strain D. J Gen Microbiol 42, 371-380.

Steuber, J., Arendsen, A. F., Hagen, W. R. \& Kroneck, P. M. H. (1995). Molecular properties of the dissimilatory sulfite reductase from Desulfovibrio desulfuricans (Essex) and comparison with the enzyme from Desulfovibrio vulgaris (Hildenborough). Eur J Biochem 233, 873-879. 
Trüper, H. G. (1984). Phototrophic bacteria and their sulfur metabolism. In Sulfur, its Significance for Chemistry, for the Geo-, Bio-, and Cosmosphere and Technology, pp. 367-382. Edited by A. Müller \& B. Krebs. Amsterdam: Elsevier.

Trüper, H. G. \& Fischer, U. (1982). Anaerobic oxidation of sulphur compounds as electron donors for bacterial photosynthesis. Philos Trans R Soc Lond Ser B Biol Sci 298, 529-542.

Voordouw, G. (1995). The genus Desulfovibrio: the centennial. Appl Environ Microbiol 61, 2813-2819.
Weaver, P. F., Wall, J. D. \& Gest, H. (1975). Characterization of Rhodopseudomonas capsulata. Arch Microbiol 105, 207-216.

Wilkinson, M. (1991). Purification of RNA. In Essential Molecular Biology, vol. 1, pp. 69-87. Edited by T. A. Brown. Oxford: Oxford University Press.

Received 6 October 1997; revised 19 January 1998; accepted 9 March 1998. 